\title{
The Correlation of Educational Standards for Museology (Ba)
}

\author{
Olga A. Masalova ${ }^{1}$, Makka I. Dolakova ${ }^{1}$, Marina A Mefodeva ${ }^{1} \&$ Adelya Sattarova $^{1}$ \\ ${ }^{1}$ Kazan Federal University, Kremliovskaya str, 18, 420008, Kazan, Russian Federation \\ Correspondence: Olga A. Masalova, Kazan Federal University, Kremliovskaya str, 18, 420008, Kazan, Russian \\ Federation. E-mail: ilgalim@bk.ru
}

Received: July 17, 2019

Accepted: October 15, 2019

Online Published: October 28, 2019

doi:10.5430/ijhe.v8n7p34

URL: https://doi.org/10.5430/ijhe.v8n7p34

\begin{abstract}
This article is devoted to the problem of correlation of the higher education system of the Russian Federation in accordance with the requirements of professional standards. The relevance of this problem is due to a radical change in approaches to personnel Museum policy and in the profile system of higher education. The most controversial issue in this study is the fragmentary implementation of professional standards in the field of Museum business and the dependence of the educational process on them. The article reveals the problems of determining the qualification requirements for a number of Museum professions, and assessing the possibility of their solution at the level of the education system. The main method of research is the method of comparative analysis, which allowed to determine the content load of the definitions used and to correlate professional and educational standards in the study area. The materials of the article can be useful for the formation of working curricula in the field of museology and protection of cultural and natural heritage.
\end{abstract}

Keywords: museum, education, professional standard, educational standard, competence

\section{Introduction}

Today there are more and more questions about what a Museum worker is, how to teach the future Museum worker and who works in the Museum. If various regulations and standards explaining the specifics of the profession are not taken into consideration, then the Museum worker is a profession that has some emotional, ethical and intellectual assets. Thus, a Museum worker is not just a profession but is a vocation, love and devotion to the profession. The Museum worker is, first of all, a person who gets into the nuts and bolts of history, culture, art, appreciates the beauty and takes care of the exhibits and history. A Museum worker becomes not only the Museum explorer, but the history of cultural heritage of mankind explorer as well. And finally, the modern communication and symbolic orientation of culture as a whole allows to see the hidden mission of the Museum worker that is "making something positive" and managing "collective irrationality" (Kharchenko V., 2017; Ameen et al, 2018). Therefore, it is very important to see how official documentation regulating education and labor implementation consider this profession.

In 2013, the system of higher education of the Russian Federation in accordance with the requirements of the Bologna system moved to a two-stage education system, which became regulated by the Federal state educational standards (FSES) of higher education, which is a set of mandatory requirements for the implementation of basic professional educational programs of higher education. The content was aimed at bringing together the system of higher education and the qualification requirements applicable to the profession directly in the sphere of its production. The basic concept of the new educational standards was the concept of "competence", which replaced the concept of "qualification". At present the main purpose of education is the development of competencies, or to be precise abilities, knowledge, skills and experience in the working activity. And the concept of "qualification" was referred to the sphere of specific performance of labor functions.

At the moment, the system of higher education is in a state of grand transformation in connection with the order of the Ministry of Education and Science of the Russian Federation 01.06.2016 № 788. on the moving to FSES3++, which is tightly bound to Professional standards.

\section{Materials and Methods}

The study of this issue is based on a number of legal acts developed by the Ministry of Education and Science of the Russian Federation and the Ministry of Labor and Social Protection of the Russian Federation, as well as on the 
relevant regulatory documentation of regional subjects of the Russian Federation (for example, the Republic of Tatarstan).

\section{Results and Discussion}

One of the fundamental points of any professional standard is the connection between training and professional activities.

A government decree of the Russian Federation dated 10 February 2014 № 92 defined the Rules of participation of employers' associations in monitoring and forecasting the needs of the economy in qualified personnel, as well as in the development and implementation of the state policy in the field of secondary vocational education (SVO) and higher education (HE).

So how do educational and professional standards relate to each other?

The difference between professional and educational standards is manifested in the answers to the following questions

1. What is regulated? Professional standards are requirements for qualifications, competencies. Educational standards determine the structure and organization of the educational process.

2. Who is a designer? Professional standards are developed by a community of professionals. Educational standards are developed by the Ministry of Education and Science and by the educational and methodological associations.

3. What is noted? Professional standards note functions, technologies and knowledge, competence and skills, which a professional has to possess. The educational standards specify the competencies that should be formed by the graduate, the share of the variable and free part, as well as what educational means should be used to formulate this or that competence.

4. What are they aimed at? In professional standards, professional qualifications are determined by the level and quality of the functions performed and defined by the words "formulate", "evaluate", "work", "be able to". In educational standards, the level of mastered competencies is determined by the ability to use them and is fixed in the words

"to own", "to be able", "to be ready" (Chernykh L.V., 2014).

And what is happening in the sphere of Museum education and professional standards?

Moscow state institute of culture became the responsible organization for the development of the Professional standard in the Museum sphere. Besides, the largest vocation-related educational institutions and museums are involved in developing the Professional standard.

Professions implemented in the Museum sphere refer to unit 04 - "Culture, arts". At the moment only three professional standards have been approved and adopted for implementation, namely Professional standard of "Museum values curator", the Professional standard of "Museum pieces specialist", and the Professional standard of "Museum guide". The lack of Professional standards in other Museum professions creates a number of problems in the Museum sphere (e.g. the issues of payment rating, determination of qualification requirements, functions of Museum staff).

In addition to the developed and approved Professional standards, efficiency indexes and codes of ethics have been introduced. On the one hand, they temporarily replace missing Professional standards in the Museum; on the other hand, they stimulate Museum staff to be ready to current personnel appraisal; on the third hand, they put Russian Museum staff into the international ethical area. Upon order by the Ministry of Culture of the Russian Federation No. 920 dated 2013, the Cabinet of Ministers of the Republic of Tatarstan approved the "Sample efficiency indexes of staff activity of cultural institutions". These indexes are designed for practical and methodological support to Federal cultural agencies in order to determine incentive payments and bonuses for work performed.

At the regional level, along with the Federal one, there is a code of "Ethics and official behavior of cultural workers of the Republic of Tatarstan", representing a set of general principles and rules of professional activity, regardless of position. The code acts as an institute of morality and self-control for cultural workers of Tatarstan. Besides it aims at improving the efficiency of cultural workers to perform their scope of employment.

In 2016 the Ministry of Education and Science took measures to bring the content of the FSES to the requirements of Professional standards. But according to FSES 3++, there is no a Professional standard for "Museology and protection of cultural and natural heritage" at the moment. The project for review submitted on the website www/fgosvo.ru that is the Portal of the Federal state educational standards of higher education.

The system of higher education introduces a new FSES 3++ so that these so different necessary requirements of the labor market and the basis of the educational process would not be absolutely opposite. 
Paragraph 1.7. allows the possibility of e-learning. There are several options for e-learning: between universities that have common areas of training, between universities and professional institutions both in Russia and with foreign partners. However, educational realities have not regulated the mechanisms of accreditation of online forms of education; there are restrictions related to the status of the institution.

Paragraph 3.5 obliges universities to form a set of professional competences taking into account the register of Professional standards placed in the complex "Professional standards" of the Ministry of Labor and Social Protection of the Russian Federation (profstandart.rosmintrud.ru) (subject to relevant professional standards). As mentioned above, up to the present more than 400 Professional standards have not been put into practice yet. If there is no relevant Professional standard, then the university has no right to form competencies that were in the FSES 3+. Therefore, the implementation of open licensed training programmes and their specializations is questionable.

Paragraph 4.4.5. in respect of teaching staff requires to involve not less than $5 \%$ of the corresponding professional sphere in the educational process. But for the first time it was clarified that they should be managers and (or) employees of other organizations engaged in labor activity in the professional sphere, which is the relevant to the professional activity, the graduates of the bachelor programs are preparing (to have work experience in this professional sphere for at least 3 years).

Paragraph 4.6.2. approves the requirements of attracting employers and (or) their associations to conduct regular internal assessment of the quality of educational activities and students training.

Thus, the higher education system is obliged to implement only those competencies that meet the approved Professional standards but universities are obliged to develop curricula by pursuing a degree in "Museology and protection of cultural and natural heritage", aimed at training the Museum staff, where the specialization is approved by the Professional standards. It should be mentioned once again that these Professional standards are for Museum values curator" "Museum pieces specialist" and "Museum guide".

What can this lead to?

First of all, the reduction of the idea of higher education is aimed not only at the formation of a qualified specialist, but also a holistic personality, as this formation of a qualified specialist comes to the capturing of competencies implemented in a fairly narrow professional specification.

Secondly, the difficulties in creating possible educational and professional network are associated with restrictions on network partnership programmes, and educational licenses that Museum institutions do not have. For example, Federal universities have the right, within Russia, to create network educational programmes only with partner universities, defined by the coordination agreement of Federal universities in the implementation of network educational programmes signed by the "Club of ten", that is a network of Federal universities of the Russian Federation (2013).

Thirdly, it is very difficult to implement paragraph 4.4.5, because it requires the involvement of the representative of the employer with a scientific degree into the educational process that is a representative of the approved professional standards. Unfortunately, in the Kazan Museum environment there are not so many specialists with the appropriate academic degrees and those who occupy senior positions.

It should be noted that the actual implementation of the educational process is becoming more complex. In accordance with professional standards, the university is obliged to provide tools for the development of specific competencies. According to FSES $3++50 \%$ of practical training will be held on the basis of the employer. Depending on the subject, practical training grounds should be a museum collection, exhibition areas, specialist research laboratories. And if, in fact, this issue can be regulated, then the problem of how, who and under what conditions these practical classes will be given deserves to be asked.

Another important point connects the FSES and the Professional standard, namely the qualification of the teaching staff. According to the Professional standard, they are all required to have field-specific education. But the very professional education in museology began to be implemented only at the turn of the XX-XXI centuries. Hence, quite a large number of Museum staff is not up to modern professional standards. It used to be enough to do training courses but now they will not be taken into account by the Ministry of Labor and Social Protection.

Nowadays, it is offered several options to keep doing their professional duties: getting a second university degree, doing a master's degree or professional retraining in accordance with one of the three Professional standards in Museology. Accordingly, they now face the same challenges as the higher education system, namely, bring into line retraining programmes with professional standards. 


\section{Conclusion}

Thus, the modernization of the educational process, its multilevel system, commitment to the formation of certain professional competencies, communication with economic realities is aimed at training competitive graduates who in their subsequent activities will be able to solve and perform multitasking functions. Employers (in particular Museum workers) involvement in the educational process will link the educational process directly with the labor market. Collaborative activities will allow to form a competitive educational product, implemented at all levels: bachelor' degree, master's degree, professional retraining programmes, training courses and internships.

Talking about the perspectives of the research of this problem it is possible to define the following:

- analysis of existing corporate educational programmes in Museology,

- identification of further directions of correlation of educational standards in Museology,

- assessment of possible participation in the educational process not only of representatives of the university and museum corporations, but also of management and expert structures in the sphere of culture.

\section{Acknowledgement}

The work is performed according to the Russian Government Program of Competitive Growth of Kazan Federal University. The author confirms that the presented data do not contain a conflict of interest.

\section{References}

Ameen, A. M., Ahmed, M. F. \& Hafez, M. A. A. (2018). The Impact of Management Accounting and How It Can Be Implemented into the Organizational Culture, Dutch Journal of Finance and Management, 2(1), 02.

Chernykh L.V. (2014). What is the difference between the professional standard and the educational standard? https://infourok.ru/chem_otlichaetsya_professionalnyy_standart_ot_obrazovatelnogo_standarta-541838.htm

Code of ethics and official conduct of cultural workers of the Republic of Tatarstan dated of 20 May, (2014). № 2306 http://mincult.tatarstan.ru/kodeks-etiki-i-sluzhebnogo-povedeniya-rabotnikov.htm

Emam, S. S. \& Shajari, H. (2013). Recognition and analysis of effective factors on investors' decision making in stock exchange of Tehran, UCT Journal of Management and Accounting Studies, 1(1), 14-21.

Government Resolution of the Russian Federation (2018). On the Rules for the development and approval of Professional standards (as amended on 9 February 2018) http://docs.cntd.ru/document/902393797

Government Resolution of the Russian Federation No. 92 dated of 10 February 2014 "On approval of the Rules of participation of employers' associations in monitoring and forecasting the needs of the economy in qualified personnel, as well as in the development and implementation of the state policy in the field of secondary vocational education and higher education" http://docs.cntd.ru/document/499075966

Jaramillo, L. E. S. (2018). Malware Detection and Mitigation Techniques: Lessons Learned from Mirai DDOS Attack, Journal of Information Systems Engineering \& Management, 3(3), 19.

Kharchenko V. (2017). Museum worker: hidden meanings of the profession, Neva, 2, 229-234.

Merkibayev, T., Seisenbayeva, Z., Bekkozhanova, G., Koblanova, A. \& Alikhankyzy, G. (2018). Oppositions in the conceptual and linguistic category of time, Opción, 34(85-2), 116-148.

Order of the Ministry of Culture of Russia dated of 28.06.2013 No. 920 "On the approval of instructional guidelines on development indicators of activity efficiency subordinated cultural institutions, their heads and workers by types of organizations and the main categories of workers by public authorities of subjects of the Russian Federation and local government bodies". https://rosmintrud.ru/docs/mintrud/payment/41

Order of the Ministry of Culture of the Republic of Tatarstan dated of 12.09.2008 No. 719 "Ont the statement of approximate criteria for the efficiency of activity appraisal of workers of municipal budgetary institutions of culture". See Annex 2. Ministry of culture of the Republic of Tatarstan http://mincult.tatarstan.ru/rus/file/pub/pub_20237.pdf

Order of the Ministry of Culture of the Republic of Tatarstan dated of 21.07.2014 No. $787 \mathrm{~d}$ "On the statement of regulations on the order of personnel appraisal of the public institutions of culture and art subordinated to the Ministry of Culture of the Republic of Tatarstan". // Ministry of culture of the Republic of Tatarstan http://mincult.tatarstan.ru/rus/file/pub/pub_781329.pdf 
Professional standard "Museum values curator" approved by the order of the Ministry of Labour and Social Protection of the Russian Federation dated of 4 August 2014 № 537n http://fgosvo.ru/uploadfiles/profstandart/04.003.pdf

Professional standard "Museum pieces specialist", approved by the order of the Ministry of Labor and Social Protection of the Russian Federation dated of 4 August 2014 № 521n http://base.garant.ru/70734996

Professional standards "Museum guide", approved by order of the Ministry of Labour and Social Protection of the Russian Federation dated of 04 August 2014 No. 539H (with changes and additions from 18.03.2016) http://ivo.garant.ru/\#/document/70737152/paragraph/8:1.

Project of the Federal state educational standard of higher education by pursuing degree in 51.03.04 "Museology and protection of objects of cultural and natural heritage" (undergraduate level) http://fgosvo.ru/uploadfiles/ProjFGOSVO3++/Bak3++/510304_B_3plus_25042017.pdf.

Rodionova D.D. (2017). Correlation of Federal state educational standards and Professional standards in the light of modern trends in the development of training of museology sydents. Professional education in Russia and abroad, 4, 28-34.

Schedule of professional development and retraining of specialists in the socio-cultural sphere and art of the Republic of Tatarstan for 2016-2017 // the Ministry of Culture of the Republic of Tatarstan http://mincult.tatarstan.ru/rus/file/pub/pub_895481.pdf 